\title{
PEMBANGUNAN KONSTRUKSI RUMAH SEDERHANA BERBAHAN DASAR BETON BERTULANG DI WILAYAH RT. 1 RW.8 KELURAHAN LOKTABAT UTARA KECAMATAN BANJARBARU UTARA KOTA BANJARBARU
}

\author{
Fitriani Ridzeki, Tezar Aulia Rahman, Fathurrahman \\ Fakultas Teknik, Universitas Islam Kalimantan \\ E-mail : fitrianiridzeki@yahoo.com
}

\begin{abstract}
ABSTRAK
Kecamatan Banjarbaru Utara yang memiliki perkembangan paling pesat adalah Kelurahan Loktabat Utara sebagai pusat perdagangan dan jasa, serta jalan alternatif menuju Bandar Udara Syamsyudin Noor. Pada umumnya, kondisi tanah di Kota Banjarbaru relatif stabil dengan tingkat resiko erosi kecil, kemampuan lahan yang baik dan bertekstur tanah halus. Hal ini sangat menunjang bagi pengembangan perkotaan serta pelaksanaan kegiatan pembangunan sarana prasarana perkotaan dan infrastruktur. Untuk memberikan pengetahuan akan pembangunan rumah yang baik sebagai tempat tumbuh dan berinteraksi, maka perlu diadakan penyuluhan kepada warga ataupun buruh bangunan terkait dengan peningkatan pemahaman masyarakat tentang bangunan rumah sederhana dan gedung sesuai dengan Standar Nasional Indonesia. Dengan Program Kemitraan Masyarakat Stimulus ini masyarakat Kelurahan Loktabat Utara khususnya yang berprofesi sebagai mandor, tukang dan buruh bangunan sudah memahami cara membangun rumah sederhana sesuai Standar Nasional Indonesia
\end{abstract}

Kata kunci: rumah sederhana, standar nasional indonesia

\begin{abstract}
North Banjarbaru Subdistrict which has the fastest development is Loktabat Utara Village as a center of trade and services, as well as an alternative road to Syamsyudin Noor Airport. In general, the land in Banjarbaru City is stable with a relatively small level of erosion risk, good land capability and a fine soil texture. This is very supportive for urban development and the implementation of urban infrastructure and infrastructure development activities. To provide knowledge about building a good house as a place to grow and interact, it is necessary to hold outreach to residents or construction workers related to increasing public understanding of simple houses and buildings in accordance with Indonesian National Standards. With the Stimulus Community Partnership Program, the people of North Loktabat Village, especially for worker as foremen, masons of building construction already understand how to build simple houses according to Indonesian National Standards.
\end{abstract}

Keywords: simple house, Indonesia National Standard

\section{PENDAHULUAN}

Kecamatan Banjarbaru Utara yang memiliki perkembangan paling pesat adalah Kelurahan Loktabat Utara sebagai pusat perdagangan dan jasa, serta jalan alternatif menuju Bandar Udara Syamsyudin Noor. Secara umum, tanah di Kota Banjarbaru stabil dengan 
tingkat resiko erosi relatif kecil, kemampuan lahan yang baik dan bertekstur tanah halus. Hal ini sangat menunjang bagi pengembangan perkotaan serta pelaksanaan kegiatan pembangunan sarana prasarana perkotaan dan infrastruktur.

Salah satu kebutuhan dasar manusia adalah rumah sebagai tempat tinggal dan berlindung dari segala gangguan luar. Selain itu, rumah juga merupakan tempat yang paling menyenangkan bagi anggota rumah tangga sebagai tempat untuk tumbuh, hidup serta berinteraksi. Perkembangan pembangunan ekonomi yang pesat di perkotaaan yang dikuti dengan tingginya arus migrasi (urbanisasi) menyebabkan terjadinya perubahan yang pesat juga terhadap perkembangan ruang fisik kota, khususnya di kawasan pusat kota dan kawasan-kawasan yang semula merupakan lahan kosong atau ruang terbuka hijau berubah menjadi kawasankawasan komersial seperti perumahan.

\section{Terdapat}

beberapa permasalahan yaitu banyaknya masyarakat dalam membangun rumah sederhana tanpa perencanaan, hanya berdasarkan ketrampilan dan kebiasaan tukang setempat, selain itu kecenderungan penurunan mutu bangunan dengan penggunaan material yang kurang tepat. Namun disayangkan semakin hari harga material bangunan semakin tinggi. Hal ini menyebabkan adanya pengurangan takaran material pasir maupun semen dalam pengerjaan kontruksi yang tidak dibarengi dengan peningkatan mutu bahan sehingga berdampak pada kerusakan dinding. (Handayani, 2020). Selama ini berbagai penelitian sudah dilakukan tetapi masih belum ditemukan alternatif teknik konstruksi yang efisien serta penyediaan bahan bangunan dalam jumlah besar dan ekonomis tanpa merusak lingkungan. (Abidin, 2018) Untuk memberikan pengetahuan akan pembangunan rumah yang baik sebagai tempat tumbuh dan berinteraksi, maka perlu diadakan penyuluhan kepada warga ataupun buruh bangunan terkait dengan peningkatan pemahaman masyarakat tentang bangunan rumah sederhana dan gedung sesuai dengan Standar Nasional Indonesia.

\section{KHALAYAK SASARAN}

Sasaran utama kegiatan ini adalah warga yang berprofesi buruh bangunan dan warga lainnya seperti kepala rumah tangga,kepala desa, perangkat desa, tokoh masyarakat, pemuda dan ulama 
masyarakat di wilayah RT. 1 RW.8

Kelurahan Loktabat Utara Kecamatan

Banjarbaru Utara Kota Banjarbaru.

\section{METODE PELAKSANAAN}

KEGIATAN

Pelaksanaan Program

Kemitraan Masyarakat Stimulus tentang

Pembangunan Konstruksi Rumah

Sederhana Berbahan Dasar Beton

Bertulang di wilayah RT. 1 RW.8

Kelurahan Loktabat Utara Kecamatan

Banjarbaru Utara Kota Banjarbaru akan

dilakukan dengan metode ceramah, diskusi dan tanya jawab.

1. Tahap Persiapan

Tahap persiapan dalam kegiatan pengabdian ini adalah penyusunan pre planning. Persiapan media berupa power point dan brosur/buku panduan dengan materi penyuluhan mengenai Penyuluhan kepada Masyarakat tentang Pembangunan Konstruksi Rumah Sederhana Berbahan Dasar Beton Bertulang di wilayah RT. 1 RW.8 Kelurahan Loktabat Utara Kecamatan Banjarbaru Utara Kota Banjarbaru. Langkah pertama adalah membuat kontrak, waktu dan tempat penyuluhan dengan mitra setempat.

2. Tahap Pelaksanaan
Kegiatan penyuluhan ini dilakukan dengan cara mengumpulkan warga dengan koordinasi dengan Ketua RT setempat. Materi akan diberikan kepada para peserta berupa brosur/buku dan gambar-gambar, berikutnya dilanjutkan pelatihan dengan peralatan peraga. Diakhir pemberian ceramah dan demonstrasi peserta dipersilahkan diberi kesempatan untuk melakukan tanya jawab dengan narasumber. Diharapkan dari sini maka para peserta akan mengerti, melaksanakan dan menyebarluaskan informasi tersebut.

\section{HASIL KEGIATAN DAN}

PEMBAHASAN

Kegiatan Pengabdian pada masyarakat mengenai pembangunan konstruksi rumah sederhana berbahan dasar beton bertulang. Kegiatan ini dilaksanakan pada hari Senin, 24 Februari 2020 dengan sasaran masyarakat di wilayah RT. 01 RW. 08 Kelurahan Loktabat Utara Kecamatan Banjarbaru Utara Kota Banjarbaru dan mahasiswa program studi Teknik Sipil Universitas Islam Kalimantan MAB Banjarmasin. 
Dari kegiatan yang dilaksanakan, maka dilakukan evaluasi pada akhir kegiatan. Evaluasi dilakukan berupa diskusi dan tanya-jawab antara pemateri dan masyarakat yang mengikuti kegiatan sosialisasi tersebut. Dari hasil diskusi dan tanya jawab tersebut dapat dilihat melalui kemampuan peserta dalam menyerap materi yang diberikan. Hasil diskusi dan tanya-jawab para peserta telah mampu memahami cara membangun rumah sederhana yang berada dilokasi rawan bencana. Peserta sosialisasi khususnya para mandor, tukang dan buruh bangunan mulai mengerti dan sadar bahwa dalam membangun rumah haruslah sesuai dengan Standar Nasional Indonesia.
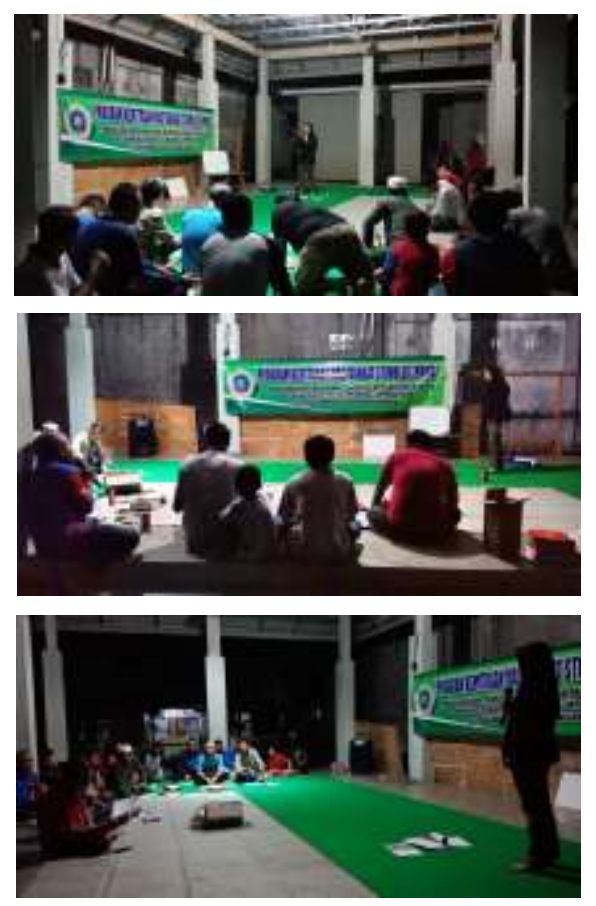

\section{KESIMPULAN}

Dengan Program Kemitraan Masyarakat Stimulus ini masyarakat Kelurahan Loktabat Utara khususnya yang berprofesi sebagai mandor, tukang dan buruh bangunan sudah memahami cara membangun rumah sederhana sesuai Standar Nasional Indonesia

Semoga kegiatan sosialisasi ini bisa terus dilanjutkan untuk beberapa kelurahan, kecamatan hingga kabupaten/kota karena mengingat wilayah provinsi.

\section{DAFTAR PUSTAKA}

Abidin, Zainal. 2018. Bata Ringan dari Campuran Limbah Sekam Padi dan Serbuk Gergajian. Jurnal Pengabdian Al Ikhlas. Volume 3 No. 2.

Christy Merril Rantung, Marthin D. J. Sumajouw, Reky S. Windah. 2014. Evaluasi Balok Dan Kolom Pada Rumah Sederhana. Universitas Sam Ratulangi Manado.

Dipohusodo, Istimawan. 1994. Struktur Beton Bertulang. Jakarta. Gramedia Pustaka Utama.

Handayani, Fitria. 2020. Alternatif Material Baru Pengolahan Dinding Bangunan Berbahan Abu Batu di Kelurahan Telaga Biru Kecamatan Banjarmasin Barat Kota Banjarmasin. Jurnal Pengabdian Al Ikhlas. Volume 6 No. 2.
PBI 1971-NI-2. Peraturan Beton Bertulang Indonesia. Badan Standarisasi Nasional.1971.


SNI 03-2847-2002. Tata Cara Perhitungan Struktur Beton untuk Bangunan Gedung. Badan Standarisasi Nasional, 2002.

SNI 03-1726-2003. Tata Cara Perencanaan Ketahanan Gempa untuk Struktur Bangunan Gedung. Badan Standarisasi Nasional, 2003.
Tavio T., I. Wimbadi, N. Kusuma, R. Tirtajaya. 2009. Effect Confinement on Interaction Diagrams of Square Reinforced Concrete Columns. Civil Engineering Dimension Volume 11 No.2 